\title{
Phytochemical screening and antioxidant activity of wild mushrooms growing in tropical regions
}

\author{
ELISA HERAWATI ${ }^{1,2}$, RICO RAMADHAN ${ }^{3,6}$, FARIDA ARIYANI $^{1}$, MARJENAH ${ }^{2,4}$, IRAWAN WIJAYA KUSUMA ${ }^{2,4,5}$, \\ WIWIN SUWINARTI ${ }^{2,4}$, DJUMALI MARDJI ${ }^{2,4}$, RUDIANTO AMIRTA ${ }^{2,4}$, ENOS TANGKE ARUNG $^{2,4,5,4}$ \\ ${ }^{1}$ Politeknik Pertanian Negeri Samarinda. Jl. Samratulangi, Sei Keledang, Samarinda 75242, East Kalimantan, Indonesia \\ ${ }^{2}$ Graduate School of Forestry, Universitas Mulawarman. J1. Penajam, Gunung Kelua, Samarinda 75123, East Kalimantan, Indonesia \\ ${ }^{3}$ Department of Chemistry, Faculty of Science and Technology, Universitas Airlangga. J1. Kampus C Mulyorejo, Surabaya 60115, East Java, Indonesia \\ ${ }^{4}$ Faculty of Forestry, Universitas Mulawarman. Jl. Penajam, Gunung Kelua, Samarinda 75123, East Kalimantan, Indonesia. \\ Tel.: +62-541-749068, Fax.: +62-541-735379, `email: tangkearung@ yahoo.com \\ ${ }^{5}$ Research Center for Drugs and Cosmetics from Tropical Rainforest Resources, Universitas Mulawarman. Jl. Ki Hajar Dewantara, Gunung Kelua, \\ Samarinda 75123, East Kalimantan, Indonesia \\ ${ }^{6}$ Division of Exploration and Synthesis of Bioactive Compounds, Research Center for Bio-Molecule Engineering, Universitas Airlangga. J1. Kampus C \\ Mulyorejo, Surabaya 60115, East Java, Indonesia
}

Manuscript received: 23 June 2021. Revision accepted: 6 October 2021.

\begin{abstract}
Herawati E, Ramadhan R, Ariyani F, Marjenah, Kusuma IW, Suwinarti W, Mardji D, Amirta R, Arung ET. 2021. Phytochemical screening and antioxidant activity of wild mushrooms growing in tropical regions. Biodiversitas 22: 4716-4721. This study aims to determine the presence of secondary metabolites which generally have bioactivity that is antioxidant with phytochemical tests and antioxidant tests in Auricularia auricula, Schyzophyllum commune, Microporus xanthopus, and Trametes versicolor fungi that grow in the wild. Phytochemical analysis was carried out by testing color changes and modifications, while antioxidant tests were carried out by using a UV-Vis spectrophotometer and a DPPH solution (1,1-diphenyl-2-picrylhydrazyl). This research found that edible wood fungus that grows, wild such as A. auricula, contains secondary metabolites, namely flavonoids, triterpenoids, saponins, and tannins, but does not contain steroids, alkaloids, carotenoids, or coumarin, while $S$. commune contains secondary metabolites, namely flavonoids, steroids, tannins, and coumarin, but does not contain triterpenoids, alkaloids, carotenoids, or saponins and non-edible wood fungus, such as M. xanthopus, contains secondary metabolites, namely, flavonoids, saponins, tannins, coumarin, and steroids, but does not contain triterpenoids, alkaloids, or carotenoids, while $T$. versicolor contains compounds, secondary metabolites, flavonoids, saponin, tannins, coumarin, and triterpenoids, but does not contain steroids, alkaloids, or carotenoids. The antioxidant test results are based on $\mathrm{IC}_{50}$ calculations; it is known that the $\mathrm{IC}_{50}$ value of $A$. auricula is $499.25 \mathrm{~g} / \mathrm{mL}$, while $S$. commune is $121.37 \mathrm{~g} / \mathrm{mL}$, M. xanthopus is $251.20 \mathrm{~g} / \mathrm{mL}$, and $T$. versicolor is $493.04 \mathrm{~g} / \mathrm{mL}$. Based on the research results, edible and inedible wood mushroom extracts contain several phytochemicals and show potential for antioxidant activity.
\end{abstract}

Keywords: Auricularia auricula, Microporus xanthopus, Schyzophyllum commune, Trametes versicolor, wood fungus

\section{INTRODUCTION}

Wood-rot fungi are wild fungi in nature that grow and live on $\operatorname{logs}$ with varying degrees of weathering, e.g. Microporus xanthopus, Auricularia auricula, Trametes versicolor, and Schyzophyllum commune. There are woodrot fungi that can be consumed, such as A. auricula and $S$. commune, while non-edible ones, such as $M$. xanthopus and $T$. versicolor, are a group of fungi that can break down cellulose and lignin so that wood becomes rotten, and the strength of its elastic fibers drops rapidly (Herliyana et al. 2011; Julian et al. 2019).

Fungi or mushrooms are plants that are heterotrophic and do not contain chlorophyll, to meet their daily needs they take ready-made food substances from other organisms. These fungi require a food source as a substrate, an energy source (from the oxidation of carbon compounds), metabolic activity (for the growth and development of hyphae), and nutrients (Arbaain et al. 2019).

Mushrooms contain various secondary metabolite compounds that contribute to various biological activity, apart from being a nutrient-rich food source and non-toxic drugs that have physiological benefits (Mirfat et al. 2010). Metabolite compounds in plants are classified into two categories, namely, primary metabolites and secondary metabolites. Primary metabolites are formed limited quantities and are used for the growth and life of organisms (Nofiani 2008). Secondary metabolites are compounds produced by organisms as protection against extreme environmental conditions or from predatory threats. Secondary metabolites are not used for growth but are transformed into primary metabolites under stressful conditions (Nofiani 2008). Secondary metabolite compounds are chemical compounds that generally have bioactivity ability to and function as protectors of these plants from pests and diseases, for the plant itself or its environment. The benefits of wood-rot fungus secondary metabolites have been reported by several researchers, including the secondary metabolite compounds of Auricularia auricula fungi that are anti-fungal (Triani et al. 2017), and potentially an anti-microbial herbal treatment for bacterial and fungal pathogens in humans (Oli et al. 2020), they also 
have potential as a functional food and natural remedy against hyperlipidemia and hepatoprotection (Zanga 2021). Auricularia polytricha mushroom has potential as an alternative therapy for diabetes mellitus (Edi 2020).

Schyzophyllum commune mushrooms show considerable antioxidant properties so that they can be promoted as a candidate for natural antioxidants in the food and pharmaceutical industries (Arbaayah 2013) and also have anti-bacterial potential (Khardziani et al. 2020). Trametes versicolor shows anti-tumor, anti-metastatic, and immunomodulation effects and can protect bones from bone damage caused by breast cancer (Luo et al. 2014), potentially increasing the total number of leukocytes and macrophages, while $M$. xanthopus shows high antimicrobial activity (Liew et al. 2015).

Under normal circumstances, the antioxidant defense system in the human body can easily overcome any free radicals that are formed (Capelli and Cysewski 2007). Free radicals are molecules that are unstable because they lose their electrons. They take electrons from other molecules or cells in our body to stabilize their charge (Gupita and Rahayuni 2012), but if there is an excess of free radicals in the body, the process of taking electrons from body cells will occur, causing cell damage that can lead to premature aging and, according to Oscar et al. (2020), can prompt the emergence of various degenerative and chronic diseases. These degenerative diseases include chronic heart disease, atherosclerosis, osteoporosis, cancer, liver cirrhosis, Alzheimer's, pulmonary obstruction, diabetes, chronic kidney disease, and stroke. The free radicals that damage body cells can be neutralized with antioxidant compounds (Iorio 2007) and these additional antioxidant compounds are generally obtained from plants.

East Kalimantan is the home of a tropical rain forest which has many kinds of wild fungi, including Auricularia auricula, Schyzophyllum commune, Microporus xanthopus, and Trametes versicolor. Therefore, the objective of this study is to examine these wild fungi for the presence of secondary metabolites and antioxidants for further application.

\section{MATERIALS AND METHODS}

\section{Plant collection and identification}

Fruit bodies of Auricularia auricula, Schyzophyllum commune, Microporus xanthopus, and Tremetes versicolor mushrooms that grow wild were obtained in the arboretum forest of the Samarinda State Agricultural Polytechnic. Identification was carried out in the silviculture laboratory of Samarinda State Agricultural Polytechnic.

\section{Preparation of extracts}

The extraction method used is maceration with $90 \%$ ethanol as the solvent. Extraction is done by dissolving mushroom powder in ethanol solvent at a ratio of $1(\mathrm{~g}): 10(\mathrm{~mL})$. The sample was then shaken using a shaker for 48 hours at room temperature, then filtered. Furthermore, using a rotary evaporator, the extract was evaporated at a temperature of $30-40^{\circ} \mathrm{C}$, until a crude extract was obtained.

\section{Phytochemical analysis}

A phytochemical test was used to screen for the presence of flavonoids, alkaloids, terpenoids, tannins, steroids, saponins, phenolics, carotenoids, coumarin and carbohydrates. Screening tests for these major phytochemicals were carried out using standard qualitative procedures, as described in Syafrizal et al. (2020), as follows:

\section{Alkaloid test}

Identification was carried out using a Dragendorff solution. The stages of making a Dragendorff solution are as follows: (i) Solution I: $0.5 \mathrm{~g}$ bismuth (III) nitrate $+6 \mathrm{~mL}$ acetic acid and $24 \mathrm{~mL}$ distilled water. (ii) Solution II: $12 \mathrm{~g}$ potassium iodide $+30 \mathrm{~mL}$ distilled water. (iii) Solution I + solution II (1mL: $1 \mathrm{~mL}$ ). (iv) To $1 \mathrm{~mL}$ of mixed solution add $2 \mathrm{~mL}$ of acetic acid and $10 \mathrm{~mL}$ of distilled water, then the solution is ready for use. As much as $5 \mathrm{~mL}$ of mushroom extracts was added, plus $2 \mathrm{~mL}$ of $\mathrm{KCl}$, then 1 $\mathrm{mL}$ of Dragendorff solution. A change in the color of the solution to orange or red indicates that the extract contains alkaloids

\section{Flavonoid test}

To $1 \mathrm{~mL}$ of mushroom extract add a few drops of dilute sodium hydroxide $(1 \% \mathrm{NaOH})$. The appearance of a clear yellow color in the extract solution that fades to colorless after the addition of dilute acid (1\% HCL) indicates the presence of flavonoids.

\section{Triterpenoid and steroid test}

Put $1 \mathrm{~mL}$ of mushroom extract that has been dissolved in acetone in a test tube, then add 10 drops of anhydrous acetic acid and 2 drops of concentrated sulfuric acid, respectively; then the test tube is shaken and left for a few minutes, the reaction that occurs is followed by a color change, if it is red or purple it means positive for triterpenoid, if it is green and blue it means positive for steroid.

\section{Tannin test}

The test was carried out by putting $10 \mathrm{~mL}$ of the mushroom extract solution into a test tube and adding $1 \%$ $\mathrm{Pb}\left(\mathrm{CH}_{3} \mathrm{COO}\right)_{2}$ solution. Tannins are present when a yellow precipitate is formed during the reaction.

\section{Saponin test}

Put $1 \mathrm{~mL}$ of mushroom extract that has been dissolved in acetone into a test tube, then add $10 \mathrm{~mL}$ of hot water. The solution is cooled and shaken for 10 seconds, if a foam is formed that stays for \pm 10 seconds with a height of 1-10 $\mathrm{cm}$ and does not disappear if 1 drop of HCL $2 \mathrm{~N}$ is added, it means Saponin is present.

\section{Carotenoid test}

A total of $1 \mathrm{~mL}$ of mushroom extract was mixed with 5 $\mathrm{ml}$ of chloroform in a test tube, shaken, and filtered; then $85 \%$ sulfuric acid was added. If a blue color forms on the surface, it indicates the presence of carotenoids. 


\section{Coumarin test}

A total of $1 \mathrm{~mL}$ of mushroom extract is mixed with a few drops of $\mathrm{NaOH}$, then alcohol is added. If a yellow color forms, it indicates the presence of coumarin.

\section{Antioxidant activity}

To test for antioxidant activity a spectrophotometer is used at room temperature $\left(25^{\circ} \mathrm{C}\right)$ with a wavelength of 514 $\mathrm{nm}$ and a solution of DPPH (1,1-diphenyl-2-picrylhydrazyl) as a free radical, with vitamin $\mathrm{C}$ as a positive control. The antioxidant analysis method used in this study is based on the method in Syafrizal et al. (2020), but with modifications. Ethanol extracts of solutions of wood mushrooms $A$. auricula and S. commune, M. xanthopus, and T. versicolor, which grow wild in nature, with concentrations of $50 \mathrm{~g} / \mathrm{mL}$, $100 \mathrm{~g} / \mathrm{mL}, 200 \mathrm{~g} / \mathrm{mL}, 300 \mathrm{~g} / \mathrm{mL}$ were taken and as much 2 $\mathrm{mL}$ of DPPH solution in ethanol was added. Then, this mixture was shaken and stored in a dark room for 30 minutes to complete the reaction, the absorbance was then measured using an UV-Vis spectrophotometer at a wavelength of $514 \mathrm{~nm}$. The test was carried out 3 times and the absorbance value obtained was used to calculate the percentage of inhibition using the formula:

Inhibition $(\%)=\underline{(\text { Absorbance control-Absorbance sample })} \times 100$ Absorbance control

To determine the value of the extract concentration that can inhibit free radical activity by $50 \%$, an inhibitor concentration with a valued of $50 \% \quad\left(\mathrm{IC}_{50}\right)$ is used (Molyneux 2004). The $\mathrm{IC}_{50}$ value is obtained from linear regression by replacing the $y$ value of 50 in the equation $y$ $=\mathrm{a}+\mathrm{bx}$.

The antioxidant power level of the $\mathrm{IC}_{50}$ value follows the categories in Jun et al. (2003), where it is a strong category if the $\mathrm{IC}_{50}$ value is $<50(\mu \mathrm{g} / \mathrm{mL})$, an active category if the $\mathrm{IC}_{50}$ value $=50-100(\mu \mathrm{g} / \mathrm{mL})$, a moderate category if the $\mathrm{IC}_{50}$ value $=101-250(\mu \mathrm{g} / \mathrm{mL})$, a weak category if the value of $\mathrm{IC}_{50}=251-500(\mu \mathrm{g} / \mathrm{mL})$ and an inactive category if the value of $\mathrm{IC}_{50}$ is $>500(\mu \mathrm{g} / \mathrm{mL})$.

\section{RESULTS AND DISCUSSION}

\section{Phytochemical analysis}

Phytochemical testing was carried out to determine the presence of secondary metabolites in each mushroom extract, such as alkaloids, flavonoids, triterpenoids, steroids, carotenoids, saponins, tannins, and coumarins.

It is known that in the extracts from the two mushrooms only 4 kinds of secondary metabolites were detected, 2 of which were the same, namely, flavonoids and tannins. In the mushroom A. auricula triterpenoid and saponin compounds were detected but no steroids or coumarins, while in the mushroom S. commune steroid and coumarin compounds were detected but no triterpenoids or saponins. Neither alkaloids nor carotenoids were detected in $A$. auricula or S. commune .

Two non-edible wood mushrooms, M. xanthopus and $T$. versicolor that grow wild in nature, as shown in Table 1, were found to contain the same 4 secondary metabolites, namely, flavonoids, saponins, tannins, and coumarins. The mushroom $M$. xanthopus was founf to contain steroids but not triterpenoids, while $T$. versicolor was found to contain triterpenoids but not steroids. Neither M. xanthopus nor $T$. versicolor was found to contain secondary metabolites of alkaloids and carotenoids.

Documentation of edible and non-edible mushrooms from field findings for Auricularia auricula, Schizophyllum commune, Microporus xanthopus, and Trametes versicolor species can be seen in Figure 1.

The results of phytochemical tests on wild mushroom extracts with extraction using different solvents include: Deka et al. (2017) extraction using ethanol as solvent, Auricularia auricula mushroom extract was found to contain saponins, tannins, steroids, terpenoids, and flavonoids, while Oli et al. (2020) reported that after extraction with a warm water solvent, A. auricula mushroom extract was found to contain flavonoid compounds, alkaloids, saponins, and tannins.

Table 1. Phytochemical results for mushrooms that grow wild in nature

\begin{tabular}{lcccccccc}
\hline Mushroom & Alk & Fla & Tri & Ste & Car & Sap & Tan & Cou \\
\hline A. auricula & - & + & + & - & - & + & + & - \\
S. commune & - & + & - & + & - & - & + & + \\
M. xanthopus & - & + & - & + & - & + & + & + \\
T. versicolor & - & + & + & - & - & + & + & + \\
\hline
\end{tabular}

Note: Alk: Alkoloids, Fla: Flavanoids, Tri: Triterpenoids, Ste: Steroids, Car: Carotenoids, Sap: Saponins, Tan: Tannins dan Cou: Coumarin
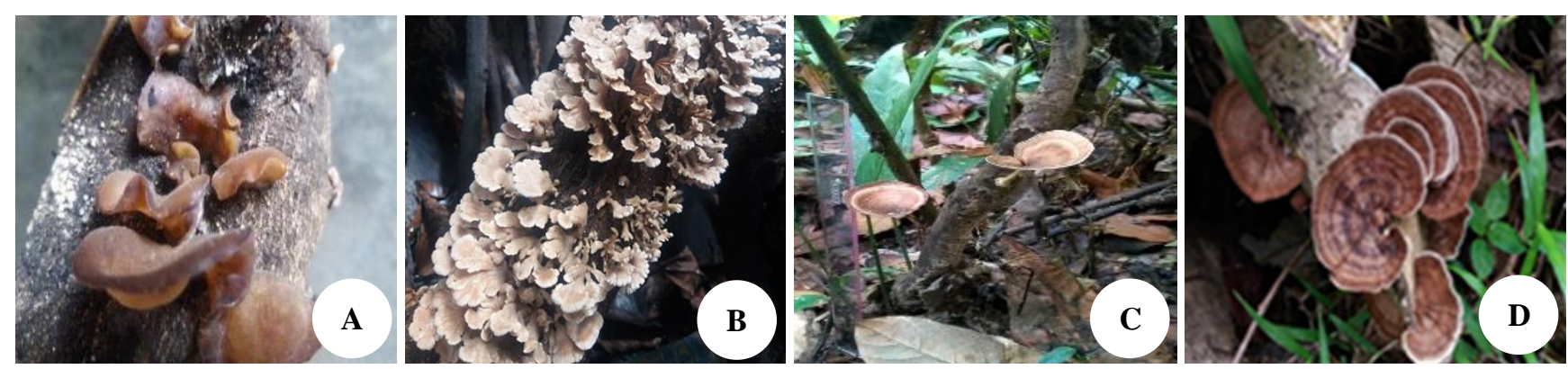

Figure 1. Wild musrooms growing in tropical regions: A. A. auricula, B. S. commune, C. M. xanthopus, D. T. versicolor 
The secondary metabolite compounds of $S$. commune mushrooms were researched by Teoh and Don (2013) via extraction using methanol as solvent, the metabolite compounds detected were flavonoids, saponins, and phenols. In the results of the study by Kumar et al. (2018) with extraction using distilled water, extracts from $S$. commune mushrooms were found to contain flavonoid compounds, alkaloids, tannins, and saponins, and in the results of research by Ekowati et al. (2020) with extraction using chloroform and ethyl acetate, extracts from $S$. commune mushrooms were found to contain terpenoids, flavonoids, and alkaloids.

The secondary metabolite content of Microporus xanthopus mushrooms extracted with chloroform solvent was found to contain alkaloids, flavonoids, steroids, and triterpenoids, while extraction with methanol solvent detected alkaloids, flavonoids, and steroids (Chittaragi and Megalatha 2014). Obama-Engonga et al. (2018) performed extraction using ethanol solvent, a phytochemical test on M. xanthopus mushroom extract was found to contain alkaloids, flavonoids, and coumarin compounds.

The secondary metabolite content of Trametes versicolor mushroom extract using an ethanol solvent was found to contain alkaloids, flavonoids, terpenoids, and steroids (Leliebre-Lara et al. 2015). After extraction using a water solvent, a phytochemical test on secondary metabolite compounds of $T$. versicolor mushrooms detected saponins, tannins, flavonoids, steroids, and terpenoids (Chengo et al. 2016).

Phytochemical screening of extract ingredients in several studies has shown different results. Several factors that influence extraction are the extraction method, sample particle size, storage conditions and time, extraction time, the ratio of the number of samples to the amount and type of solvent used (Tan et al. 2013).

The effectiveness of the extraction of a compound by a solvent depends on the solubility of the compound in the solvent, according to the like dissolve like principle, which is that a compound will dissolve in a solvent with the same properties. The acquisition of compounds is based on similarity in polarity to the solvent (Verdiana et al. 2018). Polar solvents can extract quaternary alkaloid compounds, phenolic components, carotenoids, tannins, sugars, amino acids, and glycosides. Semi-polar solvents are capable of extracting phenolic compounds, terpenoids, alkaloids, glycines, and glycosides. Non-polar solvents can extract chemical compounds such as waxes, lipids, and volatile oils (Harborne 2006).

\section{Antioxidant activity}

The results of the antioxidant activity test for mushroom extracts growing wild in nature are shown in Table 1.

Based on the level of antioxidant power $\mathrm{IC}_{50}$ following the categories of Jun et al. (2003), the $\mathrm{IC}_{50}$ value of wildgrowing Schizophyllum commune was in the medium category, while Auricularia auricula was in the weak category (Table 2). The inhibition graph (\%) of antioxidant activity test results from edible mushroom extracts that grow wild in nature can be seen in Figure 2.
Based on the level of antioxidant power $\mathrm{IC}_{50}$ follows the categories of Jun et al. (2003), IC $\mathrm{IC}_{50}$ values of Microporus xantophus and Trametes versicolor that grow wild are included in the weak category (Table 2). Vitamin $\mathrm{C}$ as positive control was in very strong category. The graph of inhibition (\%) of the antioxidant activity test results from non edible mushrooms extracts that grow wild in nature can be seen in Figure 3.

The secondary metabolite content of wood-rot fungi $A$. auricula, S. commune, M. xanthopus, and T. versicolor from the phytochemical screening results of this study indicated the presence of flavonoid compounds, triterpenoids/steroids, tannins, and saponins/coumarins. The presence of these compounds indicates potential antioxidant activity in these mushrooms. Ghasemzadeh and Ghasemzadeh (2011) state in their research that phenolic compounds and flavonoids make a linear contribution to antioxidant activity, so there is a positive relationship between the presence of tannins, flavonoids, and coumarins and antioxidant activity. Verdiana et al. (2018) suggest that flavonoids and terpenoids have very strong antioxidant activity.

Table 2. Antioxidant activity of mushroom extracts based on $\mathrm{IC}_{50}$ values.

\begin{tabular}{llc}
\hline Mushroom & Linear regression & $\begin{array}{l}\mathbf{I C}_{\mathbf{5 0}} \\
(\boldsymbol{\mu g} / \mathbf{m L})\end{array}$ \\
\hline Auricularia auricula & $\mathrm{Y}=0.103 \mathrm{x}-1.273$ & 499.249 \\
Schizophyllum commune & $\mathrm{Y}=0.276 \mathrm{x}+16.619$ & 121.046 \\
Microporus xantophus & $\mathrm{Y}=0.238 \mathrm{x}-9.686$ & 251.200 \\
Trametes versicolor & $\mathrm{Y}=0.103 \mathrm{x}-0.870$ & 494.455 \\
Ascorbic acid (Vitamin C) & $\mathrm{Y}=5.9881 \mathrm{x}+18.759$ & 5.217 \\
\hline
\end{tabular}

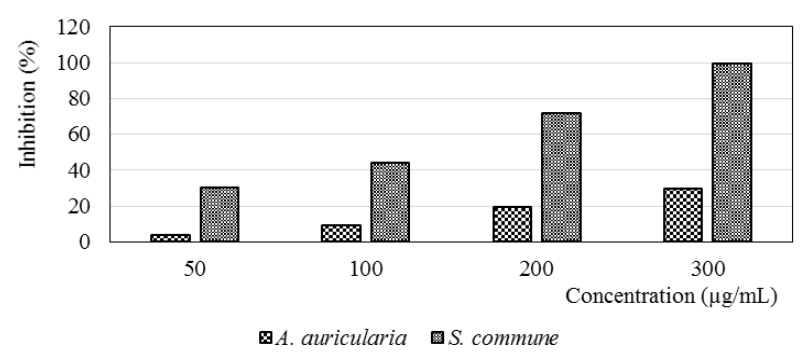

Figure 2. Inhibition (\%) graph for A. auricula and S. commune extracts

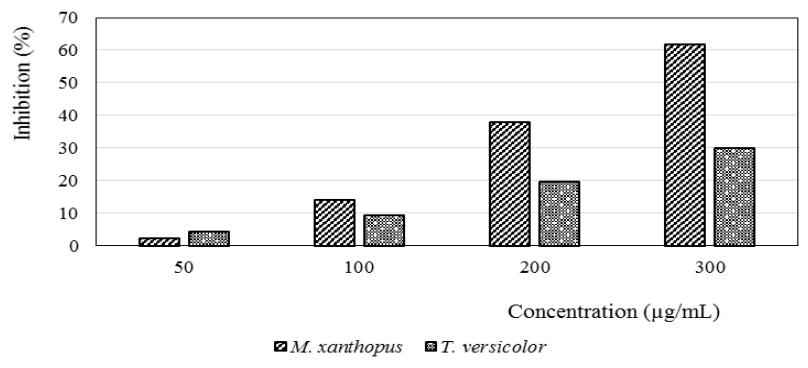

Figure 3. Inhibition (\%) graph for M. xantophus and T. versicolor extracts 
Although the mushrooms A. auricula, S. commune, $M$. xanthopus, and $T$. versicolor showed potential for antioxidant activity, the results from this study were categorized as moderate and weak. Several researchers have indicated the factors that result in weak antioxidant potential, even though several secondary metabolites were detected in these natural ingredients.

Susanto et al. (2018) state that low levels of antioxidants may be caused by improper extraction methods, low extract purity, and the presence of impurities in extracts. The sample drying process is also very influential in reducing antioxidant activity (Luiana et al. 2018). Extraction using solvents with different polarities will produce different polyphenol components so that the antioxidant properties of each compound obtained from extraction are also different (Pambayun et al. 2007).

Firdiyani et al. (2015) reported in the results of their research that the solvent greatly affects the antioxidant activity of fresh Spirulina platensis. The antioxidant activity of acetone solvent was stronger than ethyl acetate solvent. Acetone as a polar solvent can attract non-polar to polar bioactive compounds, while ethyl acetate which is a semi-polar solvent is only able to attract non-polar to semipolar bioactive compounds. Each type of solvent has a different polarity, and the same type of solvent with different concentrations also has different polarities (Tan et al. 2013)

Nurjanah et al. (2014) state that, qualitatively, a steaming process did not cause changes in bioactive components but did affect antioxidant activity. The content of vitamin $\mathrm{C}$ and beta carotene in fresh ginger after a steaming process decreased with increasing cooking time.

The temperature when drying an extracted sample has a significant effect on the content of bioactive compounds and antioxidant properties analyzed. Free radical inhibition decreases in the following order: fresh sample > air-dried sample > sample dried at $40^{\circ} \mathrm{C}>$ sample dried at $70^{\circ} \mathrm{C}$ (Gąsecka et al. 2020).

Antioxidant ability is influenced by the presence of secondary metabolite compounds. Secondary metabolite compounds that have potential for antioxidant activity are also closely related to the influence of the growing environment. This is evidenced by the more stressful the growing environment, the stronger the antioxidant activity (Wardani et al. 2020).

In summary, the results of this study indicate that although the presence of secondary metabolites such as flavonoids, triterpenoids/steroids, tannins, and saponins/coumarins was detected, which generally have antioxidant activity in $A$. auricula, S. commune, $M$. xanthopus, and $T$. versicolor mushrooms, they did not show very strong antioxidant activity. Further studies should be conducted on domesticated mushrooms with various substrates to evaluate their phytochemical and antioxidant activity.

\section{ACKNOWLEDGEMENTS}

The present study was financially supported by a Brilliant Kaltim Stimulant Scholarship from the East Kalimantan Provincial Government, Indonesia in 20142016.

\section{REFERENCES}

Arbaain EN, Bahrin EK, Noor NM, Ibrahim MF, Ramli N, Abd-Aziz S. 2019. Chemical-free pretreatment of unwashed oil palm empty fruit bunch by using locally isolated fungus (Schizophyllum commune ENN1) for delignification. Food Bioprod Process 118: 207-216. DOI: 10.1016/j.fbp.2019.09.001

Arbaayah HH, Kalsom UY. 2013. Antioxidant properties in the oyster mushrooms (Pleurotus spp.) and split gill mushroom (Schizophyllum commune) ethanolic extracts. Mycosphere 4 (4): 61-673. DOI: $10.5943 /$ mycosphere/4/4/2

Capelli, Bob, Gerald Cysewski. 2007. Natural Astaxanthin. The world's best kept health secret. Cyanotech Corporation, Kailua-Kina.

Chengo JK Adipo N, Kiboi DM, Lusweti JM, Mwatha J, Mwitari PG, Ngule CM, Njagi SM. 2016. Antiproliferative activity of kenyan Trametes versicolor aqueous extract on selected cancer and normal cell lines. J Cancer Sci Ther 8 (11): 277-282. DOI: 10.4172/19485956.1000427

Chittaragi A, Meghalatha R. 2014. Evaluation of phytochemical and anthelmintic activity of Microporus xanthopus of different solvent extracts. Int J Innov Appl Res 2 (7): 9-13.

Deka AC, Sarma I, Dey S, Sarma TC. 2017. Antimicrobial properties and phytochemical screening of some wild macrofungi of RaniGarbhanga Reserve Forest Area of Assam, India. Adv Appl Sci Res 8 (3): $17-22$.

Edi DO. 2020. Potensi jamur kuping hitam (Auricularia polytricha) sebagai terapi alternatif diabetes melitus. J Health Sci Physiother 2 (1): 9-14. [Indonesian]

Ekowati N, Mumpuni A, Ratnaningtyas NI, Maharaning AR. 2020. Compounds detection and inhibition activity of chloroform and ethyl acetate extracts of Schizophyllum commune on some cancer cell types. Biodiversitas 21 (12): 5865-5871. DOI: 10.13057/biodiv/d211251

Firdiyani F, Agustini TW, Ma'ruf WF. 2015. Ekstraksi senyawa bioaktif sebagai antioksidan alami Spirulina platensis segar dengan pelarut yang berbeda. JPHPI 18 (1): 28-37. DOI: 10.17844/jphpi.2015.18.1.28 [Indonesian]

Gąsecka M, Siwulski M, Magdziak Z, Budzyn'ska S, Stuper-Szablewska K, Niedzielski P, Mleczek M. 2020. The effect of drying temperature on bioactive compoundsand antioxidant activity of Leccinum scabrum (Bull.) Gray and Hericium erinaceus (Bull.) Pers. J Food Sci Technol 57 (2): 513-525. DOI: 10.1007/s13197-019-04081-1

Ghasemzadeh A, Ghasemzadeh N. 2011. Flavonoids and phenolic acids: Role and biochemical activity in plants and human. J Med Plants Res 5 (31): 6697-6703. DOI: 10.5897/JMPR11.1404

Gupita CN, Rahayuni A. 2012. Pengaruh berbagai Ph sari buah dan suhu pasteurisasi terhadap aktivitas antioksidan dan tingkat penerimaan sari kulit buah manggis. J Nut Coll 1(1): 209-215. DOI: 10.14710/jnc.v1i1.428 [Indonesian]

Harborne JB. 2006. Metode Fitokimia: Penuntun Cara Modern Menganalisis Tumbuhan. Diterjemahkan oleh Kosasih Padmawinata dan Iwang Soediro. Penerbit ITB, Bandung. [Indonesian]

Herliyana EN, Maryam LF, Hadi YS. 2011. Schizophyllum commune FR, sebagai jamur uji ketahanan kayu Standar Nasional Indonesia pada empat jenis kayu rakyat: Sengon ( $P$. falcataria), Karet (H.brasiliensis), Tusam (P.merkusii), Mangium (A.mangium). J Silvikul Trop 2 (3) : 176-180. [Indonesian]

Iorio EL. 2007. The measurement of oxidative stress. International observatory of oxidative stress, free radicals and antioxidant systems. Special supplement to Bulletin.

Julian AV, Reyes R, Eguchi F. 2019. Agro-industrial waste conversion into medicinal mushroom cultivation. DOI: 10.1016/B978-0-12409548-9.11042-5

Jun M, Fu H-Y, Hong J, Wan X, Yang CS, Ho C-T. 2003. Comparison of antioxidant activities of isoflavones from kudzu root (Puerarua 
labata Ohwi). J Food Sci 68 (6): 2117-2122. DOI: 10.1111/j.13652621.2003.tb07029.x

Khardziani T, Metreveli E, Didebulidze K, Elisashvili V. 2020. Screening of georgian medicinal mushrooms for their antibacterial activity and optimization of cultivation conditions for the split gill medicinal mushroom, Schizophyllum commune BCC64. Int J Med Mushrooms 22 (7): 659-669. DOI: 10.1615/IntJMedMushrooms.2020035051

Kumar A, Ali S, Lal SB, Sinha MP. 2018. Mycochemical screening and determination of nutritive potency and antioxidant activity of edible macrofungi Dacryopinax spathularia (Schwein) and Schizophyllum commune (Fries). World J Pharm Res 7 (16): 1311-1321. DOI: 10.20959/wjpr201816-13240

Leliebre-Lara V, García M, Nogueiras C, Monzote L. 2015. Qualitative analysis of an ethanolic extract from Trametes versicolor and biological screening against Leishmania amazonensis. Emirates J Food Agric 27 (7): 592-595. DOI: 10.9755/ejfa.2015.05.194

Liew GM, Khong HY, Kutoi CJ. 2015. Phytochemical screening, antimicrobial and antioxidant activities of selected fungi from Mount Singai, Sarawak, Malaysia. Int J Res Stud Biosci 3 (1): 191-197.

Luliana S, Riza H, Iswahyudi I. 2018. Effect of drying method on antioxidant activity of ethanol extract of Physalis angulata $\mathrm{L}$. Farmasains 5 (1): 15-19.

Luo KW, Yue GGL, Ko CH, Lee JKM, Gao S, Li LF, Li G, Fung KP, Leung PC, Lau CBS. 2014. In vivo and in vitro anti-tumor and antimetastasis effects of Coriolus versicolor aqueous extract on mouse mammary 4T1 carcinoma. Phytomedicine 21 (8-9): 1078-1087. DOI: 10.1016/j.phymed.2014.04.020

Mirfat AHS, Noorlidah A, Vikineswary S. 2010. Scavenging activity of Schizophyllum commune extracts and its correlation to total phenolic content. J Trop Agric Food Sci 38 (2): 231-238.

Molyneux P. 2004. The use of the stable free radical Diphenylpicrylhydrazyl (DPPH) for estimating antioxidant activity. J Sci Technol 26 (2): 211-219.

Nofiani R. 2008. Urgensi dan mekanisme biosisntesis metabolit sekunder mikroba laut. Jurnal Natur Indonesia 10 (2) : 120-125. DOI: 10.31258/jnat.10.2.120-125 [Indonesian]

Nurjanah N, Jacoeb AM, Nugraha R, Permatasari M, Sejati TK. 2014 Perubahan komposisi kimia, aktivitas antioksidan, vitamin $\mathrm{C}$ dan mineral tanaman genjer (Limnocharis flava) akibat pengukusan. Asian J Innov Entrepreneurship 3 (03): 185-195. DOI 10.20885/ajie.vol3.iss3.art3. [Indonesian]

Obame-Engonga LC, Orango-Bourdette JO, Eyi-Ndong HC, NdongAtome GR, Rick-Léonid NMM, Sima-Obiang C, Ondo JP. 2018 Chemical screening, antioxidant potential and antiangiogenic effect of Microporus Xanthopus (fr.) Kuntze, Ganoderma Orbiforme (fr.) Ryvarden and Polyporus Fasciculatus (pat) lloyd, medicinal mushrooms from Gabon. Am J Pharm Health Res 6 (10): 14-29. DOI: 10.46624/ajphr.2018.v6.i10.002

Oli AN, Edeh PA, Al-Mosawi RM, Mbachu NA, Al-Dahmoshi HOM, AlKhafaji NOR, Ekuma UO, Okezie UM, Saki M. 2020. Evaluation of the phytoconstituents of Auricularia auricula judae mushroom and antimicrobial activity of its protein extract. Eur J Integr Med 38: 1-7. DOI: $10.1016 /$ j.eujim.2020.101176

Oscar S, Antonio C, Marina G, Elsa R, Gabriel V. 2020. Phytochemical screening, antioxidant activity, and in Vitro biological evaluation of leaf extracts of Hyptis suaveolens (L.) Poit. South Afr J Biol 128: 6266. DOI: 10.1016/j.sajb.2019.10.016

Pambayun R, Gardjito M, Sudarmadji S, Kuswanto KR. 2007. Kandungan fenol dan sifat antibakteri dari berbagai jenis ekstrak produk gambir (Uncaria gambir Roxb). Majalah Farmasi Indonesia 18 (3): 141-146. [Indonesian]

Susanto A, Ratnaningtyas NI, Ekowati N. 2018. Aktivitas antioksidan ekstrak tubuh buah jamur paha ayam (Coprinus comatus) dengan pelarut berbeda. Majalah Ilmiah Biologi BIOSFERA: A Sci J 35 (2): 63-68. DOI: 10.20884/1.mib.2018.35.2.566 [Indonesian]

Syafrizal, Ramadhan R, Kusuma IW, Egra S, Shimizu K, Kanzaki M, Arung ET. 2020. Diversity and honey properties of stingless bees from meliponiculture in East and North Kalimantan, Indonesia. Biodiversitas 21 (10): 4623-4630. DOI: 10.13057/biodiv/d211021

Tan MC, Tan CP, Ho CW. 2013. Effects of extraction solvent system, time and temperature on total phenolic content of henna (Lawsonia inermis) stems. Int Food Res J 20: 3117-312.

Teoh YP, Don MM. 2013. In vitro antifungal activities and phytochemical analysis of filamentous white-rot fungi, Schizophyllum commune. Sains Malay 42 (9): 1267-1272.

Triani, Rahmawati, Turnip M. 2017. Aktivitas antifungi ekstrak metanol jamur kuping hitam (Auricularia polytricha (Mont.) Sacc.) terhadap Aspergillus flavus (UH 26). Jurnal Labora Medika 1 (2): 14-20. [Indonesian]

Verdiana M, Widarta IWR, Permana IDGM. 2018. Pengaruh jenis pelarut pada ekstraksi menggunakan gelombang ultrasonik terhadap aktivitas antioksidan ekstrak kulit buah lemon (Citrus limon (Linn.) Burm F.) J Ilmu Teknologi Pangan 7 (4): 213-222. DOI: 10.24843/itepa.2018.v07.i04.p08 [Indonesian]

Wardani YK, Kristiani EBE, Sucahyo. 2020. Correlation between antioxidant activity and phenolic compound content and plant growth locations of Celosia argentea Linn. Bioma: Berkala Ilmiah Biologi 22 (2): 136-142. [Indonesian]

Zanga Y, Li X, Yang Q, Zhang C, Song X, Wang W, Jia L, Zanga J. 2020. Antioxidation, anti-hyperlipidaemia and hepatoprotection of polysaccharides from Auricularia auricula residu. Chem Biol Interact 333: 109323. DOI: 10.1016/j.cbi.2020.109323 